УДК 78.071.1:780.614.331(477.83/.86)"1920/1930"
DOI https://doi.org/10.31723/2524-0447-2021-32-1-4

Юрій Іванович Волощук
ORCID: 0000-0003-0676-0222

кандидат мистецтвознавства, доцент,

доцент кафедри виконавського мистецтва

Прикарпатського національного університету імені Василя Стефаника

yurii.voloshchuk@pnu.edu.ua

\title{
ЖАНРОВО-СТИЛЬОВА ПАЛІТРА СКРИПКОВОЇ МУЗИКИ КОМПОЗИТОРІВ СХІДНОЇ ГАЛИЧИНИ 20-30-X РОКІВ ХХ СТОЛІТТЯ
}

Мета роботи - проаналізувати скрипкову творчість українських композиторів Східної Галичини 20-30-х років ХХ століття в аспекті виявлення взаємодії регіональних, загальнонаціональних та європейських культуротворчих та художньо-естетичних тенденцій. Методологія дослідження грунтується на комплексному підході у розгляді культурологічних процесів, які охоплюють як історико-культурний, так $i$ художньо-естетичний аспекти. На різних етапах дослідження було використано комплекс взаємопов'язаних і взаємодоповнюваних методів, зокрема теоретичного пошуку (аналіз, синтез, систематизація теоретичних даних) та музикознавчого аналізу. Наукова новизна полягає у тому, що автором досліджено стильові напрями та жканри української скрипкової музики композиторів Східної Галичини протягом 20-30-х років ХХ століття; виявлено низку неопублікованих скрипкових композицій, які можуть поповнити навчально-педагогічний репертуар учнів та студентів. Висновки. Активізація професійної музично-освітньої та концертної діяльності в Галичині, котра була пов'язана з відкриттям Союзу співацьких і музичних товариств (1903), Вищого музичного інституту (1903) i Музичного товариства імені М. Лисенка (1907), спричинила позитивні зміни в композиторській творчості. Остаточним завершенням процесу професіоналізації можна вважати створення 1934 року Союзу украӥнських професійних музик, у діяльності якого критерій музичного професіоналізму стає визначальним. Професіоналізація музикотворчого процесу сприяла розширенню жканрово-стильових орієнтирів, збагаченню структурно-композиційних форм. Поруч із обробками народних мелодій, варіаціями, рапсодіями, фантазіями, думками, шумками та іншими жсанрами з'являються перші твори великої форми - скрипкові сонати. Серед стильових напрямів скрипкової музики українських композиторів окресленого періоду домінуючими були позиції неокласицизму, неоромантизму, неоімпресіонізму та неофольклоризму.

(C) Волощук Ю. І., 2021 
Новітні тенденції в розвитку окресленої галузі були пов'язані насамперед з постатями професійних музикантів - В. Барвінського, В. Витвицького, М. Колесси, З. Лиська, С. Людкевича, Р. Придаткевича.

Ключові слова: скрипкове мистецтво, скрипкова музика, композиторська творчість, жанр, стильовий напрям, Східна Галичина.

Voloshchuk Yurii Ivanovych, Candidate of Art History, Associate Professor, Associate Professor at the Department of Performing Arts of Vasyl Stefanyk Precarpathian National University

Genre and style palette of violin music of Eastern Galicia composers in the 20-30s of the 20th century

Research objective of the work is to analyze the violin music creativity of Eastern Galicia Ukrainian composers in the 20-30s of the 20th century in terms of identifying the interaction of regional, national, European cultural, artistic and aesthetic trends. The research methodology is based on an integrated approach in the consideration of culturological processes, which cover both historical-cultural and artistic-aesthetic aspects. At different stages of the study, a set of interconnected and complementary methods was used, in particular: theoretical search (analysis, synthesis, theoretical data systematization) and musicological analysis. The scientific novelty is that the author explores the stylistic trends and genres of Ukrainian violin music created by Eastern Galicia composers during the 20-30s of the twentieth century; a number of unpublished violin compositions have been discovered, which can supplement the educational and pedagogical repertoire of pupils and students. Conclusions. Intensification of professional music-educational and concert activities in Galicia, which was associated with the foundation of the Union of Singing and Music Societies (1903), the Higher Music Institute (1903) and the Lysenko Music Society (1907), caused positive changes in compositional work. The creation of the Union of Ukrainian Professional Musicians in 1934, in whose activities the criterion of musical professionalism became decisive, can be considered the final completion of the process of professionalization. The professionalization of the music-making process contributed to the genre and style landmarks expansion, structural and compositional forms enrichment. Along with arrangements of folk melodies, variations, rhapsodies, fantasies, thoughts, noises and other genres, the first works of large form appeared violin sonatas. Among the violin music stylistic trends of Ukrainian composers in the outlined period, the positions of neoclassicism, neo-romanticism, neoimpressionism and neo-folklore were dominant. The newest tendencies in the development of the outlined branch were connected foremost with the personalities of professional musicians such as V. Barvinsky, V. Vytvytsky, M. Kolessa, Z. Lysko, S. Lyudkevych, R. Prydatkevych.

Key words: violin art, violin music, compositional work, genre, stylistic trend, Eastern Galicia.

Актуальність теми дослідження. Вивчення історії європейського скрипкового мистецтва як цілісного та взаємо- 
пов'язаного явища неможливе без грунтовного і всебічного аналізу зародження, становлення та розвитку національних виконавських і педагогічних шкіл, їх традицій та специфіки функціонування. Складовою частиною цього завдання $\epsilon$ дослідження еволюційних процесів у скрипковому мистецтві Східної Галичини, яке пройшло тривалий шлях, збагативши світову музичну культуру іменами яскравих виконавців, талановитих педагогів та композиторів. Зокрема, досить яскравою та самобутньою є скрипкова творчість українських композиторів регіону першої третини XX століття, яка мала безпосередній вплив на формування національного інструментального стилю у загальноєвропейському контексті. Проте здебільшого вченими-музикознавцями досліджується камерно-інструментальна, фортепіанна та вокальна музика Західної України, а сольна скрипкова творчість залишається поза увагою.

Мета дослідження - проаналізувати скрипкову творчість українських композиторів Східної Галичини 20-30-х років XX століття в аспекті виявлення взаємодії регіональних, загальнонаціональних та європейських культуротворчих та художньо-естетичних тенденцій.

Наукова новизна полягає у тому, що автором досліджено стильові напрями та жанри української скрипкової музики композиторів Східної Галичини протягом 20-30-х років $\mathrm{XX}$ століття; виявлено низку неопублікованих скрипкових композицій, які можуть поповнити навчально-педагогічний репертуар учнів та студентів.

Виклад основного матеріалу. Активізація професійної музично-освітньої та концертної діяльності в Галичині, котра була пов'язана з відкриттям Союзу співацьких і музичних товариств (1903), Вищого музичного інституту (1903) і Музичного товариства імені М. Лисенка (1907), спричинила позитивні зміни в композиторській творчості. Остаточним завершенням цього процесу професіоналізації, що відповідав етапові зрілості нації, можна вважати створення 1934 року Союзу українських професійних музик (далі - СУПроМ). Якщо в музичних установах початку століття було чимало аматорів, то в діяльності СУПроМу критерій музичного професіоналізму стає визначальним. Ця музична спілка об'єднала музикантів, які переважно здобули освіту в кращих вищих школах Європи, та організувала їх у чотирьох секціях (композитор- 
ській, музикознавчій, педагогічній і виконавській), визначаючи таким чином чотири напрями своєї діяльності.

Композиторська секція, до якої входили Василь Барвінський, Нестор Нижанківський, Станіслав Людкевич, Василь Витвицький, Стефанія Туркевич, Микола Колесса, Роман Сімович та інші, визначалася насамперед своєрідним обличчям так званої «празької школи», тобто тих музикантів, які отримали вишкіл у В. Новака у Празькій школі вищої майстерності. Важливим аспектом діяльності композиторської секцї СУПроМу було окреслення шляху розвитку нової української музики, спрямованого в бік європейської професіоналізаціі зі збереженням неповторного національного обличчя.

У 20-30-х роках XX ст. українська музика Галичини почала наближатися до русла, в якому розвивалася європейська музична культура. Тому в галузі скрипкової музики (сольної та ансамблевої) цей період позначений різким загостренням художньо-стильової конфронтації між різними напрямами, стрімкою зміною нових художніх течій - тенденціями, характерними для розвитку композиторської творчості в країнах Европи першої половини ХХ століття.

Проте слід звернути увагу на ту особливість, що у сфері скрипкової музики більшість творів була написана композиторами-аматорами (М. Гайворонський, І. Левицький, Я. Ярославенко та інші), котрі дотримувались традиційних стилістичних і формотворчих принципів. Тому новітні тенденції в розвитку зазначеної галузі були пов'язані перш за все з постатями професійних музикантів - В. Барвінського, В. Витвицького, М. Колесси, 3. Лиська, С. Людкевича, Р. Придаткевича.

Професіоналізація музикотворчого процесу сприяла розширенню жанрово-стилістичних горизонтів, збагаченню структурно-композиційних форм. Поруч із жанрами, які активно культивувалися ще в попередній період (обробки народних мелодій, варіаціі, рапсодії, фантазіі, думки, шумки та інші), з'являються перші твори великої форми - скрипкові сонати. До цього жанру зверталися В. Барвінський, Б. Кудрик, Р. Придаткевич, С. Туркевич-Лукіянович. Але порівняно з галицькою камерною фортепіанною музикою, де соната привертала увагу багатьох композиторів, у галузі скрипкової музики цей жанр перебував на етапі становлення.

Незначна популярність скрипкових сонат у галицькій музичній творчості була зумовлена двома чинниками. 
По-перше, оскільки процес становлення скрипкового мистецтва Галичини в попередні періоди був тісно пов'язаний із побутуванням скрипки в народному середовищі, то, відповідно, жанр сонати не мав тут розвинених традицій. По-друге, позаяк тільки незначна частина галицьких композиторів орієнтувалася у скрипковій фактурі і технічних можливостях інструменту, володіла знанням драматургічних особливостей будови сонатного циклу, то продукування творів великої форми становило певні труднощі.

На жаль, жодна зі скрипкових сонат, створених українськими музикантами Галичини 1919-1939 рр., не була знайдена. Тому всі відомості про розвиток цього жанру скрипкової творчості можна почерпнути з деяких наукових розвідок, заміток у тогочасній періодичній пресі та часописах.

Для розвитку скрипкової музики Галичини 20-30-х рр. XX ст. характерна низка напрямів:

- домінування творчих позицій неоромантизму;

- зародження рис імпресіонізму;

- поява експресіоністичних тенденцій;

- звернення до неокласичних музичних орієнтацій;

- започаткування неофольклористичного спрямування.

Ці напрями і тенденції виступають як у чистому вигляді, так і у взаємодії між собою. Спільною для них рисою $є$ те, що вони, «адаптуючись» у скрипковій музиці Галичини, набули помітно «слов'янізованого» звучання.

Зростання національно-визвольного руху сприяло подальшому поширенню романтизму в галицькій музиці. Для композиторів-романтиків характерне глибоке проникнення у внутрішній світ людини, ліризм та емоційність звучання, широке використання народного матеріалу. У процесі розвитку нових жанрів романтичної музики чітко простежується національно-романтична тенденція, пов'язана 3 перетворенням народного епосу й оновленим трактуванням пісенного фольклору. Українські композитори Галичини найчастіше звертаються до тематичного матеріалу, пов'язаного з історією та національно-визвольною боротьбою народу, національними традиціями, фантастичними та казковими сюжетами, ліричними образами. Тому для періоду 20-30-х pp. XX ст. характерний подальший розвиток жанрів варіацій, фантазії, рапсодії, обробок народних пісень і танців, а також вальсу, мазурки, ноктюрну, елегії. 
Скрипкова музика постромантичного спрямування стала предметом творчих експериментувань таких композиторів, як С. Людкевич, І. Левицький, Я. Ярославенко, М. Гайворонський, Я. Барнич, В. Витвицький, А. Гнатишин, Е. Форостина.

Романтичні традиції превалюють у творчості видатного західноукраїнського композитора С. Людкевича. Працюючи над написанням творів різних жанрів, він прагнув до синтезування досягнень світової музичної культури з особливостями національного музичного мислення, чим сприяв розвиткові композиторського професіоналізму.

Серед творів С. Людкевича 1919-1939 років є дві скрипкові мініатюри: «Чабарашка» (1920) і «Тихий спомин» (1921). «Тихий спомин» цікавий передусім своєю програмною основою. Це твір мрійливого характеру з деякими відтінками елегійності, що написаний під враженням нарису В. Стефаника «Вечірня година». У цій скрипковій мініатюрі знаходимо взірці витонченого ліризму, вираження душевної теплоти, тонке розуміння духовного світу.

Найбільший інтерес 3 усіх скрипкових мініатюр Людкевича становить «Чабарашка» - своєрідна «творча стилізація» в дусі народного танцю. У «Чабарашці» вражає тонке відтворення не тільки особливостей народних танцювальних мелодій, але й виконавського стилю народних музикантів-скрипалів. В основі п’єси лежить тема, зразком для створення якої послужили народні коломийки-чабарашки. Для «Чабарашки» характерний коломийковий ритм і специфічні риси мелодичної лінії (невеликий діапазон, повторність коротких поспівок).

Доволі велика кількість сольних та ансамблевих скрипкових композицій, написаних у національно-романтичному плані, належить перу Михайла Гайворонського (1892-1949). Незважаючи на те, що у 1923 році митець переїхав до Сполучених Штатів Америки, його твори постійно поповнювали педагогічний і концертний репертуар українських скрипалів і залишили помітний слід у скрипковій культурі Галичини.

Скрипкова творчість М. Гайворонського різноманітна за жанрами та образно-тематичною сферою. Значне місце у його композиторському доробку посідають твори, безпосередньо чи опосередковано пов’язані з народною музикою. До скрипкових сольних композицій такого спрямування належать 
«Варіації на українську тему», «Українські танці», «Українські народні пісні», «Рапсодія». Серед ансамблевих творів вирізняються струнні квартети «Морозенко», «Різдвяна сюїта» та «Коломийка» для струнного тріо.

У творчій спадщині М. Гайворонського є низка скрипкових п'єс, написаних у традиційних романтичних жанрах: «Елегія», «Колискова», «Пісня без слів», «Серенада». Композиторська діяльність митця спирається на лисенківський принцип народності в музиці (особливо в обробках народних пісень). Водночас відчутний вплив на формування творчого почерку композитора представників «перемишльської школи» (Матюк, Воробкевич), сентименталізм яких був близький його ліричній вдачі.

Про стиль М. Гайворонського можна судити з його листа, написаного А. Рудницькому 1945 р., в якому він, зокрема, зазначає: «Композиції дуже мелодійні і догідні до виконання; видержані під оглядом форми, дух у них український; лаконічні та непереладовані; гармонії суто консервативні і банальні; маю нахил до поліфоніі. Живучи в часах «нової ери» української музики, головну увагу звернув на збереження нашого питомого культурного доробку, а в музичній мові найбільше спільного находив з матеріалом інших старих, українських композиторів...» [8, с. 145].

Найвагоміше місце в розвитку романтичних жанрів сольної скрипкової музики в Галичині впродовж 20-30-х років належить композиторові, скрипалю-виконавцю і педагогу Івану Левицькому (1875-1938). Прекрасно володіючи скрипкою, знаючи іiі технічні й виразові можливості, він створив велику кількість композицій, які виконувалися на різноманітних музичних імпрезах у Галичині, вивчались учнями Вищого музичного інституту імені М. Лисенка. Для творчості I. Левицького притаманне образно-тематичне розмаїття та багатожанровість.

Важливим джерелом творчості композитора була народна музика. Це сприяло зверненню до жанрів, які вже мали міцні традиції в українській музиці: обробки народних мелодій, варіації, рапсодія, думка, шумка, сюїта. Серед таких творів найціннішими $є$ «Українська шумка», «Другий український танок», «Українська рапсодія», «Мережка».

У період 1919-1939 років одночасно 3 домінуючим у скрипковій музиці Галичини неоромантичним напрямом 
3’являються нові модерні течії, які співіснують, взаємодіють чи навіть конфліктують з ним і між собою на різних рівнях художнього мислення.

Значна роль у процесі модерного оновлення української музичної традиції належить представникам так званої «празької школи». Їхня творчість була позначена глибокою увагою до духу українського фольклору, а джерела інноваційних тенденцій, аналогічно до витоків західного модернізму, полягали в прагненні подолати певний культурно-естетичний традиціоналізм у національній музиці.

Вагомий вплив на оновлення музичної мови у скрипковому жанрі мав європейський імпресіонізм, який визначався зацікавленістю пейзажами, миттєвими змінами настрою музики, витонченою технікою чистих тонів. У галицькій музиці імпресіонізм виявився насамперед через посилення барвно-колористичного фактору в гармонії та оркестровці.

Найяскравішим українським композитором, який зумів поєднати національну образність зі стилістикою тогочасної імпресіоністичної та пізньоромантичної музики, був Василь Барвінський. Вплив імпресіоністичної техніки найбільше позначився на принципах гармонії та фактури композитора. Варто підкреслити, що сполучити імпресіоністичну гармонію i традиційні жанри української музики було досить важко. Тому митець використовує виразові можливості варіантно-варіаційних форм, найбільш поширених у національному фольклорі. Видозмінюючи початковий варіант теми, Барвінський впроваджує типові імпресіоністичні прийоми - об’ємну, просторову фактуру або колористичні гармонічні зіставлення.

Романтична традиція втілюється через «образно-емоційну настроєність, яка зародилась у романтичну добу: перевага суб’єктивно-ліричного начала, камерності, елегійності, колористики народних «образів» [7, с. 17].

У низці скрипкових творів В. Барвінського, написаних у 30-х роках, чітко простежується синтез як постромантичних, так і імпресіоністичних рис. Серед таких композицій виразним національним колоритом i новочасними музичними засобами виокремлюються «Народна мелодія» $\mathrm{i}$ «Гумореска».

«Народну мелодію» засновано на найтиповіших українських мелодичних зворотах. Ї̈̈ початковий мотив нагадує відому ліричну пісню «Ой, не світи місяченьку». Розвиваючи цей наспів, композитор подає його в різних варіантах, користу- 
ючись підголосковими та імітаційними проведеннями. Імпресіоністичного забарвлення п'єсі надають часті тональні зіставлення епізодів, якими композитор користується у середній частині тричастинної форми. Особливо характерним є впровадження репризи, спочатку в тональності шостого мінорного ступеня і лише згодом в основній тональності - ля мінор.

В основі «Гуморески» лежить танцювальна тема 3 перемінною акцентністю, оспівуванням неопорних звуків і прихованою синкопованістю. У фортепіанній партії басові квінти 3 форшлагами наголошують слабкі долі тактів - чвертки, що викликає ритмічні зміщення щодо вісімкових синкоп мелодіі. Середину тричастинної форми - невеликий епізод у повільному темпі - засновано на ліричній українській пісні з насиченим підголосками акомпанементом.

Підсумовуючи аналіз творчості В. Барвінського, відзначимо, що «кожна зі скрипкових мініатюр композитора характеризується майстерним втіленням народних джерел, характеру і колориту пісні чи танцю, філігранною відточеністю форми і найменшої її деталі» [6, с. 51].

Оригінальною й модерною музичною мовою і значним доробком у галузі скрипкової музики вирізняється творчість Романа Придаткевича. Серед його творів, написаних для скрипки з фортепіано, виокремлюються «Гуцульська сюїта», «Козацька сюїта», «Перша українська рапсодія», «Прелюдія, хорал і фуга», соната Fis-dur, велика кількість малих форм («Весільний начерк», «Пісня про чабана», три мініатюри на основі народних пісень).

Народна пісня і танець стали основним джерелом творчих шукань Р. Придаткевича. Наприклад, у скрипковому творі «Прелюдія, хорал і фуга» темою хоралу є пісня «Пречиста Діво Мати». Окремі частини «Першої української рапсодії» також тематично пов'язані з народною пісенністю. Рясне використання фольклорної тематики наявне у «Козацькій сюїті», «Гуцульській сюїті» та багатьох інших композиціях.

Проте слід відзначити, що в процесі опрацювання фольклорного матеріалу Придаткевич відходить від примітивного етнографізму. Народна тема є для нього тільки вихідною точкою, з якої він самостійно розвиває власну творчу думку, іiі мистецьке оформлення. За твердженням тогочасного музикознавця і композитора 3. Лиська, «його досить відважні, барвисті гармонії, уміння і спосіб поліфонічного мислення, 
різноманітне оркестрове звучання, опанування ним великих форм є складниками того своєрідного стилю, що ставить музиканта в ряд найновітніших українських композиторів» [5, c. 22].

Ще однією модерною течією, вплив якої відчутний і в струнно-смичковій музиці Галичини, був неофольклоризм. Його витоки пов'язують перш за все з музикою Бартока, деякими творами Стравінського і Прокоф'єва. Зародження неофольклоризму в Галичині спричинене переосмисленим ставленням композиторів до давніх пластів фольклору як до джерела нової музичної виразовості.

Цей процес найповніше репрезентує творчість М. Колесси: «Колесса намагається вживати в своїх творах не безпосередню тематику народних пісень, але іiі первні, iіi питомий характер... У цьому творчому підході Колесса йде слідами мадярського композитора Белі Бартока, який своїми творами започаткував у сучасній музиці новий напрям: сполуки первнів народної музики з яскраво-модерною музичною мовою», - пише 3 цього приводу у своєму історично-критичному огляді «Українська музика» А. Рудницький [8, с. 170].

Особливо яскраво виявляється нове опанування фольклору в камерно-інструментальних творах Колесси кінця 20-30-х років. Це, зокрема, його квартет для фортепіано, скрипки, альта і віолончелі. У квартеті «яскравий стилізовано-фольклорний тематизм поєднується з жорсткими гармонійними (полігармонійними) конструкціями, з ускладненим тональним (політональним, атональним) мисленням, 3 часто нерегулярною ритмікою і неквадратними побудовами» $[9$, c. 28].

Тричастинний фортепіанний квартет М. Колесси відрізняється від попередніх ансамблів експресивною музичною мовою, великою динамічністю форми і своєрідною драматургією, за якої фінал фокусує найвагоміші тематичні елементи твору й стає «центром ваги» всього циклу.

Неофольклоризм не знайшов утілення у сольній скрипковій музиці галицьких композиторів періоду 1919-1939 рр. Проте окремі творчі спроби в цьому напрямі мали певний вплив на розвиток галузі та яскравіше виявилися протягом наступних етапів її еволюції.

Емоційні та естетичні протиріччя, пов'язані з тенденціями модернізму, спричинили повернення до естетичних орієнти- 
рів класицизму. Музичне мислення знову спрямовувалось до виразності мелосу, прозорості гармонії та фактури, простоти форм, чіткості інтонаційних конструкцій, характерних для творчості Ж. Рамо і Ф. Куперена, Й. Гайдна і В. Моцарта.

Неокласичні музичні тенденції поширилися у творчості галицьких композиторів різних мистецьких спрямувань й орієнтацій. Проте неокласицизм в українській музиці Галичини не може трактуватися однозначно, лише як повернення до формотворчих і стилістичних традицій минулого та їх синтез із сучасними виражальними засобами. Цей новий напрям можна вважати частковою компенсацією за відсутність періоду музичної класики в Західній Україні. Новий класицизм відповідав прагненням молодих галицьких митців створити національну композиторську школу на основі апробованих часом музичних конструкцій, виразових засобів, засад розвитку.

Тенденції неокласицизму застосовувалися в різних формах і на різних рівнях музичного мислення і набули значного поширення в галузі скрипкової творчості. Добираючи жанри для написання струнно-смичкових композицій, українські музиканти віддавали перевагу скрипковій сонаті, фортепіанному тріо, струнному квартету, сюїті для скрипки 3 фортепіано. У разі побудови композиційної структури найпопулярнішим був сонатний цикл з домінуючим сонатним алегро. У взаємодії жанрового і формального рівнів з музичною мовою творів утворювались несподівані жанрово-стильові поєднання: класичні форми і типи фактури «забарвлювалися» фольклорним колоритом завдяки вживанню мелодичних, гармонічних і ритмічних елементів народної музики західноукраїнського регіону.

Найбільш плідним композитором-неокласиком у камерно-інструментальному жанрі був Борис Кудрик (1897-1950). Незважаючи на «традиційну музичну мову, близьку до віденських класиків, - як зазначає Ю. Булка, - твори Б. Кудрика знаходили шлях до слухача й визнання прискіпливої музичної критики» [1, с. 571].

Сучасна дослідниця західноукраїнської музичної культури 20-30-х pp. ХX ст. Н. Костюк доводить причетність музичного стилю композитора до епохи бідермайєра. Вона пише: «Ця ідеологічно-естетична «антитеза» творчості Б. Кудрика до загального мистецького напряму була зумовлена застережливою позицією щодо поглиблення бідермайєрівських 
тенденцій, котрі виявлялись у творах композитора найяскравіше. Класична нормативність мислення, проступаючи крізь призму почувань та виразовості бідермайєрівського сприймання, була стрижнем його стилю» [4, с. 158].

У творчому доробку Б. Кудрика $є$ ціла низка скрипкових творів, які мали популярність серед слухачів і входили до репертуару провідних виконавців.

Серед них - три сонатини для скрипки з фортепіано (g-moll, a-moll, es-moll), соната для скрипки соло, дві сонати, п’єса «Ліричні хвилини», мініатюри «Гетьманський гавот», «Арія», фортепіанне тріо, струнний квартет [3, с. 27-28]. У спогадах Василя Витвицького про музичне життя в Галичині подаються відомості стосовно менуету для скрипки й фортепіано «Спомин з Коломиї», написаного Б. Кудриком у залізничному вагоні дорогою до Львова [2, с. 59].

Про високий художній рівень скрипкових творів композитора свідчить той факт, що його соната ля мінор для скрипки й фортепіано 1932 року була нагороджена на конкурсі музичної секції Об'єднання українських організацій в Америці і 1934 року виконувалася в містах Північної Америки та Європи відомим скрипалем і композитором Р. Придаткевичем [2, с. 59]. Але, на жаль, значна частина творів Б. Кудрика була знищена після його безпідставного арешту й ув'язнення в 1945 р.

Серед віднайдених композицій - «Дитячі транскрипції 21 народної мелодії» для трьох скрипок і п’єса «Малий скрипач» для скрипки і фортепіано. Ці твори були призначені для вивчення скрипалями-початківцями, вони становлять певну цінність для поповнення сучасного педагогічного репертуару.

Висновки. Узагальнюючи розвиток скрипкової музики 20-30-х років XX століття, зазначимо, що новітні тенденціï у скрипковій творчості пов'язані насамперед з постатями професійних митців, які отримали фахову підготовку в консерваторіях Європи. Тому в їхній сольній та ансамблевій скрипковій музиці відчутне різке загострення художньо-стильової конфронтації між різними напрямами, спостерігається стрімка зміна нових художніх течій.

Для розвитку скрипкової музики Східної Галичини окресленого періоду характерним $є$ культивування низки стильових напрямів, а іноді і їх поєднання в межах одного твору. Домінуючими були позиції неокласицизму, неоромантизму, неоімпресіонізму та неофольклоризму. 
Професіоналізація музикотворчого процесу, удосконалення техніки композиторського письма, збільшення спектра засобів художньої виразності сприяли розширенню жанрово-стилістичних горизонтів, збагаченню структурно-композиційних форм. Поруч з обробками народних мелодій, інструментальними мініатюрами, варіаціями, рапсодіями, фантазіями, думками, шумками з'являються перші твори великої форми скрипкові сонати.

У цьому дослідженні накреслені лише основні тенденції розвитку музикотворчого процесу у Східній Галичині періоду першої третини XX століття. Її проблематика передбачає потребу подальшого грунтовного вивчення часткових проблем, пошуку дискографії, джерельних і нотних матеріалів, що значно збагатить українську музичну спадщину.

\section{СПИСОК ЛІТЕРАТУРИ}

1. Булка Ю.П. Музична культура Західної України. Історія української музики: у 6 т. Київ : Наукова думка, 1992. Т. 4: 1917-1941. C. 545-589.

2. Витвицький В. Музичними шляхами: спогади. Мюнхен : Едмонтон, 1989. $215 \mathrm{c}$.

3. Козулькевич Є. Українська скрипкова література. Українська музика. Львів, 1938. Ч. 2. С. 27-28.

4. Костюк Н.О. Музична культура Західної України 20-30-х років XX століття: ідеї поступу та розвиток національних традицій : дис. ... канд. мист. : 17.00.01. Київ, 1998. 267 с.

5. Лисько 3. Роман Придаткевич (до 100-річчя від дня народження). Музика. Київ, 1995. № 6. С. 22.

6. Павлишин С.С. Василь Барвінський. Київ : Муз. Україна, 1990. $88 \mathrm{c}$.

7. Павлишин С. Львівські музиканти та «празька школа». Союз Українських Професійних Музик у Львові: матеріали $i$ документи. Львів, 1997. С. 17.

8. Рудницький А. Українська музика: історично-критичний огляд. Мюнхен : Дніпрова хвиля, 1963. 406 с.

9. Стельмащук Р. Нові напрями в творчості українських галицьких композиторів першої половини ХХ століття (до 1939 року). Союз Українських Професійних Музик у Львові: матеріали $і$ документи. Львів, 1997. С. 19-20.

\section{REFERENCES}

1. Bulka, Yu.P. (1992). Muzychna kultura Zakhidnoi Ukrainy [Musical culture of Western Ukraine]. Istoriia ukrainskoi muzyky: u 6 t. Kyiv: Naukova dumka. T. 4: 1917-1941. P. 545-589 [in Ukrainian]. 
2. Vytvytskyi, V. (1989). Muzychnymy shliakhamy: spohady [Musical ways: memories]. Edmonton. 215 s. [in Ukrainian].

3. Kozulkevych, Ye. (1938). Ukrainska skrypkova literatura [Ukrainian violin literature]. Ukrainska muzyka. Lviv. Ch. 2. S. 27-28 [in Ukrainian].

4. Kostiuk, N.O. (1998). Muzychna kultura Zakhidnoi Ukrainy 20-30-kh rokiv XX stolittia: idei postupu ta rozvytok natsionalnykh tradytsii [Musical culture of Western Ukraine in the 20-th and 30-th of the XX century: ideas of progress and development of national traditions]: dys. ... kand. myst.: 17.00.01. Kyiv. 267 s. [in Ukrainian].

5. Lysko, Z. (1995). Roman Prydatkevych (do 100-richchia vid dnia narodzhennia) [Roman Prydatkevych (to the 100th anniversary of his birth)]. Muzyka. Kyin. No. 6. S. 22 [in Ukrainian].

6. Pavlyshyn, S.S. (1990). Vasyl Barvinskyi [Vasyl Barvinsky]. Kyiv: Muz. Ukraina. 88 s. [in Ukrainian].

7. Pavlyshyn, S. (1997). Lvivski muzykanty ta "prazka shkola" [Lviv musicians and the "Prague school"]. Soiuz Ukrainskykh Profesiinykh Muzyk u Lvovi: materialy i dokumenty. Lviv. S. 17 [in Ukrainian].

8. Rudnytskyi, A. (1963). Ukrainska muzyka: istorychno-krytychnyi ohliad [Ukrainian music: a historical and critical review]. Miunkhen: Dniprova khvylia. 406 s. [in Ukrainian].

9. Stelmashchuk, R. (1997). Novi napriamky v tvorchosti ukrainskykh halytskykh kompozytoriv pershoi polovyny 20 stolittia (do 1939 roku) [New directions in the work of Ukrainian Galician composers of the first half of the 20th century (until 1939)]. Soiuz Ukrainskykh Profesiinykh Muzyk u Lvovi: materialy i dokumenty. Lviv. S. 19-20 [in Ukrainian]. 